\title{
ATR inhibitor AZD6738 increases the sensitivity of colorectal cancer cells to 5-fluorouracil by inhibiting repair of DNA damage
}

\author{
TAKUYA SUZUKI $^{1}$, TAKAHISA HIROKAWA ${ }^{1,2}$, ANRI MAEDA $^{1}$, SHINNOSUKE HARATA $^{1}$, KAORI WATANABE $^{1}$, \\ TAKESHI YANAGITA ${ }^{1}$, HAJIME USHIGOME ${ }^{1}$, NOZOMI NAKAI ${ }^{1}$, YUZO MAEDA $^{1}$, \\ KAZUYOSHI SHIGA ${ }^{1}$, RYO OGAWA ${ }^{1}$, AKIRA MITSUI ${ }^{3}$, MASAHIRO KIMURA ${ }^{4}$, \\ YOICHI MATSUO $^{1}$, HIROKI TAKAHASHI ${ }^{1}$ and SHUJI TAKIGUCHI ${ }^{1}$
}

\begin{abstract}
${ }^{1}$ Department of Gastroenterological Surgery, Nagoya City University Graduate School of Medical Sciences, Nagoya, Aichi 467-8601; ${ }^{2}$ Department of Gastroenterological Surgery, Kariya Toyota General Hospital, Kariya, Aichi 448-8505; ${ }^{3}$ Department of Gastroenterological Surgery, Nagoya City University West Medical Center, Nagoya, Aichi 462-8508; ${ }^{4}$ Department of Gastroenterological Surgery, Nagoya City University East Medical Center, Nagoya, Aichi 464-8547, Japan
\end{abstract}

Received November 20, 2021; Accepted January 27, 2022

DOI: 10.3892/or.2022.8289

\begin{abstract}
The repair of DNA damage caused by chemotherapy in cancer cells occurs mainly at two cell cycle checkpoints $\left(\mathrm{G}_{1}\right.$ and $\left.\mathrm{G}_{2}\right)$ and is a factor contributing to chemoresistance. Most colorectal cancers harbor mutations in p53, the main pathway involved in the $\mathrm{G}_{1}$ checkpoint, and thus, are particularly dependent on the $G_{2}$ checkpoint for DNA repair. The present study examined the effect of AZD6738, a specific inhibitor of ataxia telangiectasia mutated and rad3-related (ATR) involved in the $\mathrm{G}_{2}$ checkpoint, combined with 5-fluorouracil (5-FU), a central chemotherapeutic agent, on colorectal cancer cells. Since 5-FU has a DNA-damaging effect, its combination with AZD6738 is likely to enhance the therapeutic effect. The effects of the AZD6738/5-FU combination were evaluated in various colorectal cancer cells (HT29, SW480, HCT116 and DLD-1 cells) by flow cytometry (HT29 cells), western blotting (HT29 cells) and water-soluble tetrazolium 1 assays (HT29, SW480, HCT116 and DLD-1 cells), as well as in an experimental animal model (HT29 cells). In vitro, the AZD6738/5-FU combination increased the number of mitotic cells according to flow cytometry, decreased the checkpoint kinase 1 phosphorylation levels and increased cleaved caspase- 3 and phosphorylated form of H2A.X variant histone levels according to western blotting, and decreased the proliferation rate of four colon cancer cell lines according to cell viability experiments. In vivo, xenografted colorectal cancer cells treated with the AZD6738/5-FU combination exhibited
\end{abstract}

Correspondence to: Dr Takahisa Hirokawa, Department of Gastroenterological Surgery, Kariya Toyota General Hospital, 5-15 Sumiyosi-cho, Kariya, Aichi 448-8505, Japan

E-mail: takahisa.hirokawa@toyota-kai.or.jp

Key words: ataxia telangiectasia mutated and rad3-related inhibitor, AZD6738, cell cycle, 5-fluorouracil, colorectal cancer a marked decrease in proliferation compared with the 5-FU alone group. The present results suggested that AZD6738 enhanced the effect of 5-FU in p53-mutated colorectal cancer.

\section{Introduction}

A variety of chemotherapeutic agents and radiation therapies are used to treat malignant tumors, including colorectal cancer. A number of these therapies induce DNA damage in cancer cells, which results in genomic instability and ultimately leads to cancer cell death. For example, 5-fluorouracil (5-FU) damages DNA by inserting 5-fluoro-2'-deoxyuridine 5'-triphosphate into DNA (1). Platinum drugs such as cisplatin and oxaliplatin damage DNA by forming cross-linked structures (2). Furthermore, radiation therapy induces DNA double-strand breaks, resulting in marked DNA damage in cancer cells (3). However, the problem with all of these therapies is that their continuous use renders the cells resistant to the therapies and decreases their effectiveness (4). The present study focused on the DNA damage response (DDR) of the cells as a factor causing this resistance.

In both normal and cancer cells, various DDR proteins are activated to maintain genomic stability, in turn activating cell activities, including cell cycle arrest, apoptosis and premature senescence (5). Dysfunction of these systems results in DNA damage accumulation, genomic instability and eventually inability of the cells to survive. In cancer cells, on the other hand, DNA damage from cancer therapies is similarly repaired by the DDR, but this results in re-stabilization and survival of cancer cells and, ultimately, in treatment failure (6).

DDR and cell cycle arrest due to DNA damage occur at cell cycle checkpoints. In mammals, there are two main checkpoints, $G_{1}$ and $G_{2}$, which serve an important role in cell survival. The former depends on the ATM serine/threonine kinase (ATM)/p53/p21 signaling pathway, while the latter depends on both the ATM/p53/p21 and ATM/ataxia telangiectasia mutated and rad3-related (ATR)/checkpoint kinase 1 (Chk1)/cell division cycle 25 (Cdc25) signaling pathways (7-11). Given that 
most cancer cells have genetic mutations in p53 (12-14), their survival after DNA damage depends on the function of the $\mathrm{G}_{2}$ checkpoint mediated by the ATM/ATR/Chk1/Cdc25 signaling pathway (15-17). Therefore, agents that can inhibit the $\mathrm{G}_{2}$ checkpoint may be promising for inducing synthetic lethality in p53-deficient cancer cells and for chemosensitization of known cancer therapies or reversal of resistance.

The agent used in the present study, AZD6738, is a cell cycle checkpoint inhibitor classified as an ATR inhibitor (18). It is a specific inhibitor of ATR that works by inhibiting phosphorylation of Chk1 (Ser345) (19,20). Preclinical studies have reported its potentiating effect on pancreatic cancer cells when combined with gemcitabine (21) and on treatment sensitivity when combined with radiation $(22,23)$. In addition, phase I and II trials are ongoing in clinical practice (24-26). However, to the best of our knowledge, its efficacy in combination with 5-FU, the mainstay chemotherapeutic agent for colorectal cancer, is still unclear. 5-FU has a damaging effect on DNA (1), and it was hypothesized that its effect was likely to be enhanced when AZD6738 was used in combination. The aim of the present study was to confirm the potentiating effect of AZD6738 with 5-FU. To the best of our knowledge, the present study was the first to investigate the effect of AZD6738 in combination with 5-FU. At present, AZD6738 is undergoing clinical trials; it has been reported to be used in combination with radiotherapy (27), and it has been reported to be effective in combination with olaparib in ovarian cancer (28). If AZD6738 is shown to be effective in combination with 5-FU, it is expected to have early clinical applications in colorectal cancer, and furthermore, it is expected to prolong overall survival. In addition, if this research progresses, it is expected to be applied to colorectal cancer that has become resistant to 5-FU by DDR.

\section{Materials and methods}

Cell culture. The human colorectal cancer cell lines (HT29, SW480, HCT116 and DLD-1) were obtained from American Type Culture Collection. HT29 has been authenticated (no. KBN0811) using short tandem repeat DNA analysis by the Japanese Collection of Research Bioresources Cell Bank. All cells were cultured in DMEM (MilliporeSigma) supplemented with 10\% FBS (Gibco; Thermo Fisher Scientific, Inc.) and 1\% penicillin/streptomycin. All cells were cultured at $37^{\circ} \mathrm{C}$ with $5 \% \mathrm{CO}_{2}$.

Reagents. AZD6738 (AstraZeneca) was used at a final concentration of $0.5 \mu \mathrm{M}$ in all cell lines, unless otherwise indicated. This concentration $(0.5 \mu \mathrm{M})$ of AZD6738 had no effect on cell proliferation at $37^{\circ} \mathrm{C}$ for $72 \mathrm{~h}$ (Fig. S1A). Unless otherwise indicated, 5-FU (FUJIFILM Wako Pure Chemical Corporation) was used at a final concentration of $5 \mu \mathrm{M}$ (for HT29 and HCT116 cells) or $25 \mu \mathrm{M}$ (for SW480 and DLD-1 cells), which are the half-maximal inhibitory concentrations at $37^{\circ} \mathrm{C}$ for $72 \mathrm{~h}$ (Fig. S1B). The concentration of nocodazole (MilliporeSigma) was $300 \mathrm{nM}$. Distilled water was used as a control in WST-1 assay (Fig. 3), western blotting (Figs. 2A and 3A) and cell cycle analysis (Fig. 1A).

Water-soluble tetrazolium 1 (WST-1) cell viability assay. The viability of HT29, SW480, HCT116 and DLD-1 cells was determined WST-1 assay. The viability of the cells was determined using the Premix WST-1 Cell Viability Assay System (Takara Bio, Inc.) according to the manufacturer's protocols. Cell lines were seeded in 96 -well plates $\left(1.0 \times 10^{4} /\right.$ well $)$ in $100 \mu \mathrm{l}$ medium and allowed to attach overnight. Once the cells had attached, they were treated with 5-FU and/or AZD6738 at $37^{\circ} \mathrm{C}$ for $72 \mathrm{~h}$. The concentration of 5 -FU was $0-1,000 \mu \mathrm{M}$ and the concentration of AZD6738 was 0-10 $\mu \mathrm{M}$. After $72 \mathrm{~h}$, $10 \mu \mathrm{l}$ WST-1 reagent was added to the plates followed by an additional incubation for $1 \mathrm{~h}$. The absorbance reading in each well was measured using a microplate reader (SpectraMax ABC; Molecular Devices, LLC) at a wavelength of $450 \mathrm{~nm}$.

Western blotting. Collected HT29 cells were suspended in SDS sample buffer $(87.5 \mathrm{mmol} / 1$ Tris- $\mathrm{HCl}, \mathrm{pH}$ 6.8, $9 \%$ glycerol, $2.75 \%$ SDS, $0.003 \%$ bromophenol blue and $150 \mathrm{mmol} / 1$ dithiothreitol; concentration, $1 \times 10^{6}$ cells $/ 150 \mu 1$ ), and treated at $98^{\circ} \mathrm{C}$ for $5 \mathrm{~min}$. For each lane, $14 \mu \mathrm{l}$ sample was dispensed, proteins in the lysates were separated on 4-20\% Mini-PROTEAN TGX Precast gels (Bio-Rad Laboratories, Inc.) and transferred to nitrocellulose membranes. The membranes were blocked in 5\% skim milk (BD Biosciences) at room temperature for $30 \mathrm{~min}$. The membranes were incubated overnight with the primary antibodies at $4{ }^{\circ} \mathrm{C}$, followed by $1 \mathrm{~h}$ of incubation with the secondary antibodies at $4^{\circ} \mathrm{C}$. Primary antibodies against the following proteins were used for western blotting: Chk1 (dilution, 1:1,000; cat. no. C9358; MilliporeSigma), phospho-Chk1 Ser345 (dilution, 1:1,000; cat. no. 2348; Cell Signaling Technology, Inc.), Apoptosis Western Blot Cocktail (dilution, 1:250; cat. no. ab136812; Abcam) for cleaved caspase-3, H2A.X variant histone (H2AX; dilution, 1:1,000; cat. no. ab11175; Abcam), phosphorylated form of $\mathrm{H} 2 \mathrm{AX}(\gamma \mathrm{H} 2 \mathrm{AX}$; dilution, 1:2,000; cat. no. 05-636; Merck KGaA) and $\beta$-actin (dilution, 1:1,000; cat. no. 3700; Cell Signaling Technology, Inc.). The secondary antibody for Chk1, $\gamma \mathrm{H} 2 \mathrm{AX}$ and $\beta$-actin was HRP-conjugated goat anti-mouse immunoglobulins $(1: 2,000$; cat. no. P0447; Agilent Technologies, Inc.). The secondary antibody for phospho-Chk1 and H2AX was HRP-conjugated goat anti-rabbit immunoglobulins (dilution, 1:1,000; cat. no. P0448; Agilent Technologies, Inc.). The secondary antibody for cleaved caspase-3 was HRP-conjugated secondary antibody cocktail of the Apoptosis Western Blot Cocktail (dilution, 1:100; cat. no. ab136812; Abcam). The protein-antibody complexes were visualized with a SuperSignal West Pico Chemiluminescent Substrate, SuperSignal West Femto Chemiluminescent Substrate (pChk1) or Pierce ECL Western Blotting Substrate (Chk1, $\beta$-actin, $\gamma \mathrm{H} 2 \mathrm{AX}, \mathrm{H} 2 \mathrm{AX}$, Cleaved-Caspase-3) (all from Thermo Fisher Scientific, Inc.). The immunoreactive protein bands were detected using an ImageQuant LAS-4000mini (Cytiva). The results were semi-quantified by densitometry analysis using ImageJ software version 1.53 (National Institutes of Health).

Cell cycle analysis. HT29 Cells were harvested at 0, 24, 48 and $72 \mathrm{~h}$ after treatment and fixed with $70 \%$ ethanol at $-20^{\circ} \mathrm{C}$ overnight. Cell pellets were washed once with PBS and DNA was stained using the Cycletest Plus DNA Reagent Kit (cat. no. 340242; BD Biosciences) following the manufacturer's instructions. The counts of cell cycle distribution 
A
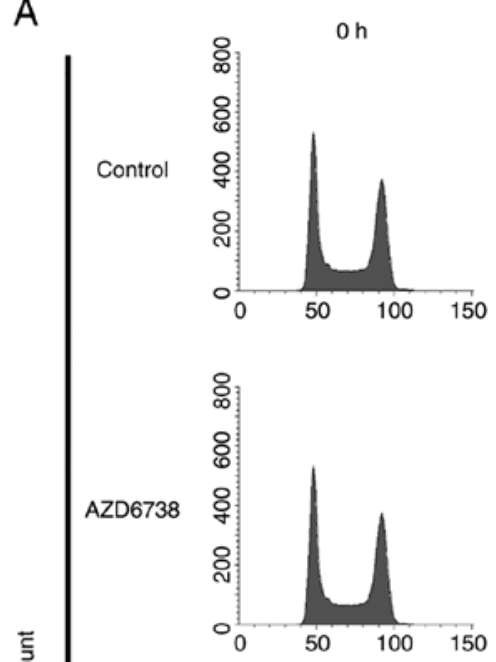

亏ัँ
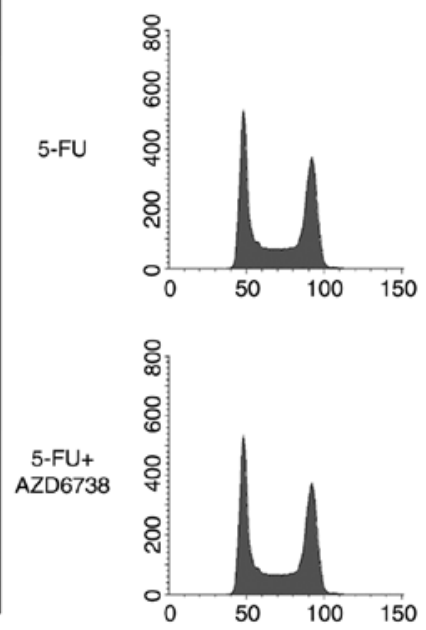

$24 \mathrm{~h}$
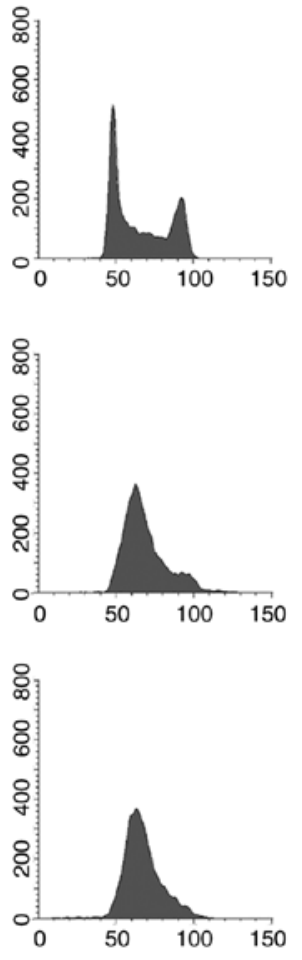

$48 \mathrm{~h}$
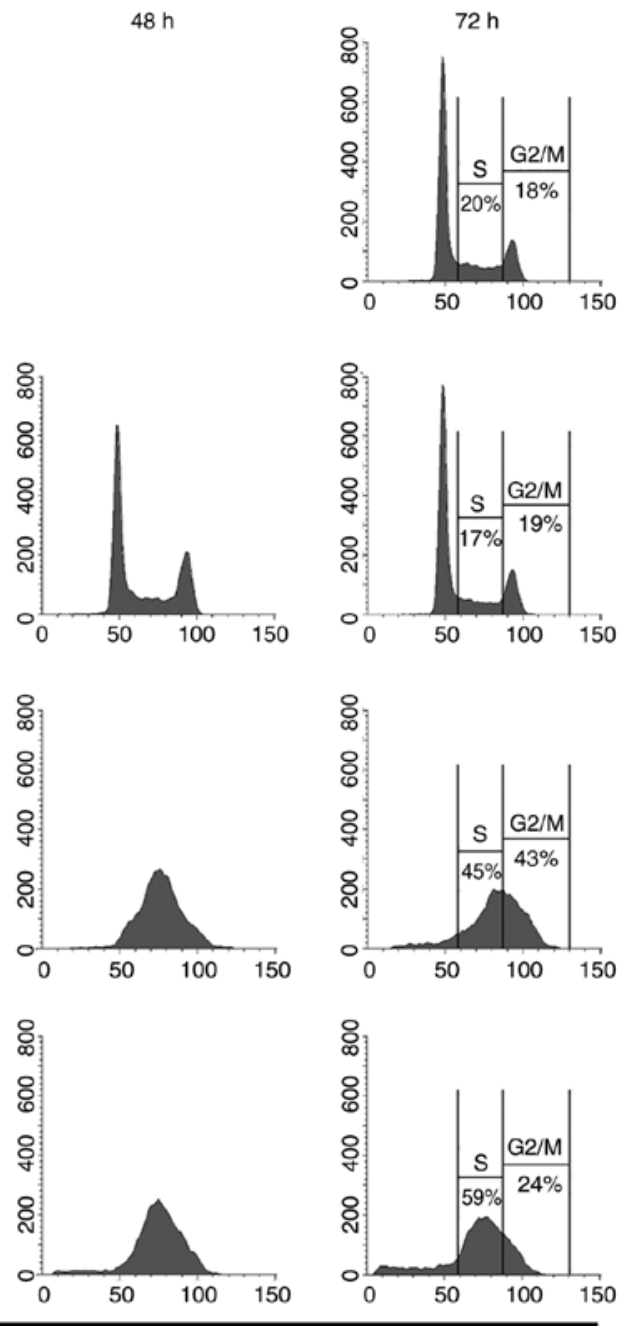

Propidium iodide-A ( $\times 1000)$

B

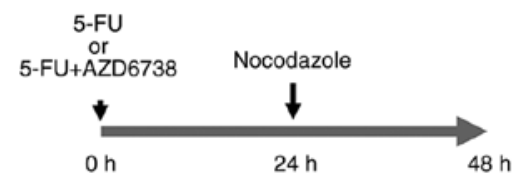

D

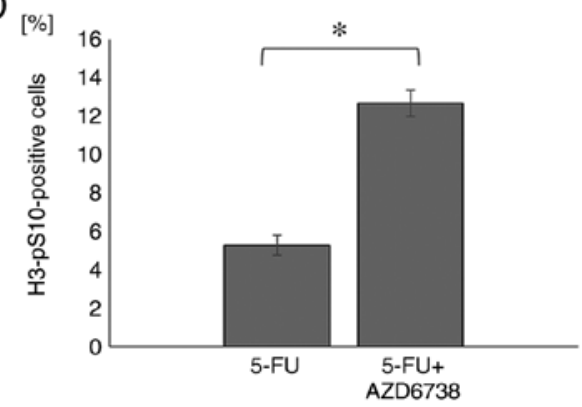

C

C

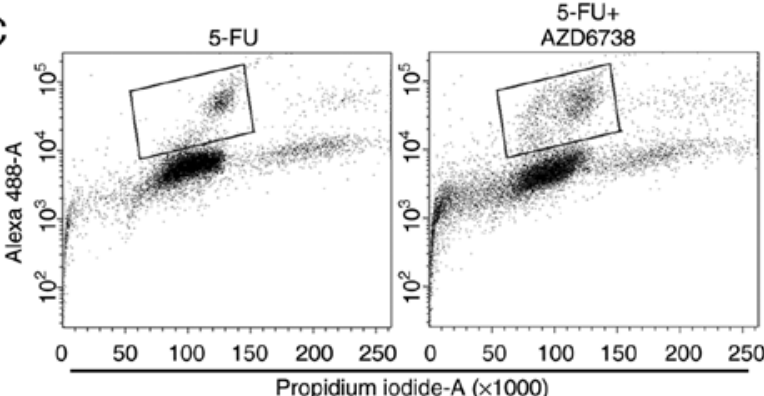

Figure 1. AZD6738 inhibits maintenance of $\mathrm{G}_{2}$ checkpoints. (A) HT29 cells were treated with 5-FU $(5 \mu \mathrm{M})$ in the presence or absence of AZD6738 (0.5 $\left.\mu \mathrm{M}\right)$. Cells were harvested at the indicated times, fixed and subjected to FACS analysis. (B) Schematic of the protocol for the nocodazole experiment. (C and D) HT29 cells were treated with 5-FU $(5 \mu \mathrm{M})$ in the presence or absence of AZD6738 $(0.5 \mu \mathrm{M})$. At $24 \mathrm{~h}$ after starting treatment, nocodazole (300 nM) was added to inhibit the exit of cells from mitosis. Cells were harvested at $48 \mathrm{~h}$, fixed, and stained with anti-H3-pS10 antibodies to determine the mitotic cells. (C) Typical examples of flow cytometry and (D) H3-pS10-positive cells are shown. Data are presented as the mean \pm SD ( $n=4)$. Statistical significance was calculated using Student's t-test ("P<0.05). 5-FU, 5-fluorouracil; H3-pS10, phospho-histone H3 at S10.

were evaluated by PI staining, and all samples were analyzed using a FACSCanto II flow cytometer (BD Biosciences) at a wavelength of $488 \mathrm{~nm}$ with the appropriate software (BD FACSDiva Software ver. 8.0.2; BD Biosciences). 
Measurement of $M$ phase cells. HT29 cells were treated with 5-FU and/or AZD6738 for $24 \mathrm{~h}$ at $37^{\circ} \mathrm{C}$, followed by treatment with nocodazole $(300 \mathrm{nM})$ for another $24 \mathrm{~h}$ at $37^{\circ} \mathrm{C}$. Nocodazole was added to prevent cells from exiting mitosis. Subsequently, the cells were fixed with $70 \%$ ethanol at $-20^{\circ} \mathrm{C}$ overnight. Cell pellets were washed once with PBS and stained with an antibody against phospho-histone H3 at S10 (dilution, 1:100; cat. no. 06-570; MilliporeSigma) for $3 \mathrm{~h}$, followed by 30 min of incubation with an Alexa Fluor 488 secondary antibody (dilution, 1:50; cat. no. ab150077; Abcam). DNA was counterstained with a BD Cycletest Plus DNA Reagent Kit (cat. no. 340242; BD Biosciences). All samples were analyzed using a FACSCanto II flow cytometer (BD Biosciences) at a wavelength of $488 \mathrm{~nm}$ with appropriate software (BD FACSDiva Software ver. 8.0.2; BD Biosciences).

Animals. The present study used female mice, referring to previous studies $(21,29)$. A total of 20 female BALB/c nu-nu mice were purchased from Japan SLC, Inc. The animals were housed in standard Plexiglas cages in a room maintained at a constant temperature $\left(20-26^{\circ} \mathrm{C}\right)$ and humidity (40-60\%) under a $12 \mathrm{~h}$ light/dark cycle. Mice had access to autoclaved chow and water ad libitum. The time interval between injection and the end of the experiment was 6 weeks. All experiments were conducted according to the Guidelines for Animal Experiments of the Nagoya City University Graduate School of Medical Sciences and approved by the Animal Care and Use Committee of the Nagoya City University Graduate School of Medical Sciences (Nagoya, Japan).

HT29 human colorectal cancer cells $\left(5 \times 10^{6}\right.$ in $200 \mu 1$ PBS) were injected subcutaneously into the right flank of each mouse ( 8 weeks old; weight range, 17.0-21.1 g/mouse). Once the tumor volume surpassed $\sim 100 \mathrm{~mm}^{3}$, the mice were randomly divided into two groups (5-FU, and 5-FU and AZD6738). Based on the results of the experiments in vitro and with reference to previous reports $(30,31)$, five mice were used in each group. In the 5-FU group, 5-FU (FUJIFILM Wako Pure Chemical Corporation) was dissolved in saline solution (Otsuka Pharmaceutical Factory, Inc.) at $2.5 \mathrm{mg} / \mathrm{ml}$ and administered to the mice at $25 \mathrm{mg} / \mathrm{kg} / \mathrm{day}$ intraperitoneally (5 times a week for 3 weeks). The solvent (10\% DMSO, $40 \%$ propylene glycol and $50 \%$ deionized sterile water) was administered at $10 \mathrm{ml} / \mathrm{kg} /$ day by oral gavage ( 5 times a week for 3 weeks). In the 5-FU and AZD6738 group, 5-FU was dissolved in saline solution (Otsuka Pharmaceutical Factory, Inc.) at $2.5 \mathrm{mg} / \mathrm{ml}$ and administered to the mice at $25 \mathrm{mg} / \mathrm{kg} /$ day intraperitoneally (5 times a week for 3 weeks). AZD6738 (AstraZeneca) was dissolved in 10\% DMSO, 40\% propylene glycol and $50 \%$ deionized sterile water at $2.5 \mathrm{mg} / \mathrm{ml}$ and administered to the mice at $25 \mathrm{mg} / \mathrm{kg} / \mathrm{day}$ by oral gavage (5 times a week for 3 weeks). The tumor volume $\left(\mathrm{mm}^{3}\right)$ was calculated as follows: (longest tumor diameter) x (shortest tumor diameter $)^{2} / 2$. Finally, the tumors were harvested from mice and fixed in $10 \%$ formaldehyde at $4^{\circ} \mathrm{C}$ for $24 \mathrm{~h}$. There was no significant difference in the weight of the mice between the two groups. To investigate the toxicity of AZD6738 alone, the same experiment was also performed on the control group and AZD6738 group. There were five mice per group. In the control group, instead of AZD6738 solution, the solvent was administered at $10 \mathrm{ml} / \mathrm{kg} /$ day by oral gavage. There was no significant difference in the weight between these two groups either. Before harvesting the tumor, all animals were euthanized by cervical dislocation under $2.0-2.5 \%$ isoflurane inhalation anesthesia using isoflurane inhalation solution. Animal death was confirmed by the loss of signs, such as heartbeat and response to toe pinch. The graying of the mucous membranes and rigor mortis of mice were also confirmed. The following were used as humane endpoints to determine that mice should be euthanized: Total tumor volume $>10 \%$ of body weight, tumor diameter $>20 \mathrm{~mm}$, tumor ulceration/necrosis, gait disturbance, and impaired water and food intake.

Immunohistochemistry. Formalin-fixed (4\% paraformaldehyde at $4^{\circ} \mathrm{C}$ for $6 \mathrm{~h}$ ), paraffin-embedded sections (3- $\mu \mathrm{m}$-thick) were mounted on 3-aminopropyltriethoxylsilane-coated slides. The sections were deparaffinized with xylene and hydrated with ethanol at $100 \%$ twice, 90,80 and $70 \%$ for 5 min each. After washing with running water, samples were soaked in $10 \mathrm{nM}$ citric acid buffer and boiled using a microwave (10 min; 600 watts). Subsequently, the slides were soaked in $100 \%$ methanol and $0.3 \%$ hydrogen peroxide mixed solution for $30 \mathrm{~min}$ to block endogenous peroxidase activity, and blocked with $4 \%$ Block Ace Powder (cat. no. UKB80; DS Pharma Biomedical Co., Ltd.) for $10 \mathrm{~min}$ in a humidity box at room temperature. The sections were stained with a primary antibody against $\gamma \mathrm{H} 2 \mathrm{AX}$ (cat. no. 05-636; dilution, 1:500; Merck KGaA) overnight at $4^{\circ} \mathrm{C}$ followed by anti-mouse EnVision+/HRP-labeled polymer (cat. no. K4001; dilution, 1:1,500; Dako; Agilent Technologies, Inc.) as secondary antibody for $45 \mathrm{~min}$ at room temperature. 3,3-diaminobenzidine substrate (cat. no. K3467; Dako; Agilent Technologies, Inc.) was used as the chromogen for detection for $10 \mathrm{~min}$ at room temperature. Hematoxylin was used for counterstaining for $30 \mathrm{sec}$ at room temperature. The result was presented as the mean percentage of $\gamma \mathrm{H} 2 \mathrm{AX}$-positive cells \pm SD per high-power field. Ten fields of view were examined for each tumor. The slides were imaged with a fluorescence microscope (BZ-X710; Keyence Corporation) and examined using the BZ-X710 Analyzer (1.4.0.1) software (Keyence Corporation) (32).

Statistical analysis. All statistical analyses were performed using JMP software version 14.3.0 (SAS Institute, Inc.). All data are presented as the mean \pm standard deviation. Comparisons between two groups were performed using Student's t-test (unpaired t-test). Comparisons among more than two groups were performed using one-way analysis of variance followed by Tukey's test. $\mathrm{P}<0.05$ was considered to indicate a statistically significant difference.

\section{Results}

AZD6738 abrogates 5-FU-induced activation of the $G_{2} / M$ checkpoint. First, to investigate whether the combination of AZD6738 and 5-FU resulted in cell cycle perturbations in HT29 cells, which lack functional p53 (33), the cell cycle profiles were evaluated by flow cytometry at 24,48 and $72 \mathrm{~h}$ after treatment with AZD6738 $(0.5 \mu \mathrm{M}), 5-\mathrm{FU}(5 \mu \mathrm{M})$, their combination or control (Fig. 1A). At 24 and $48 \mathrm{~h}$, the cell cycle was similar in the 5-FU group and the 5-FU+AZD6738 combination group, but at $72 \mathrm{~h}$, the percentage of cells in the 
A

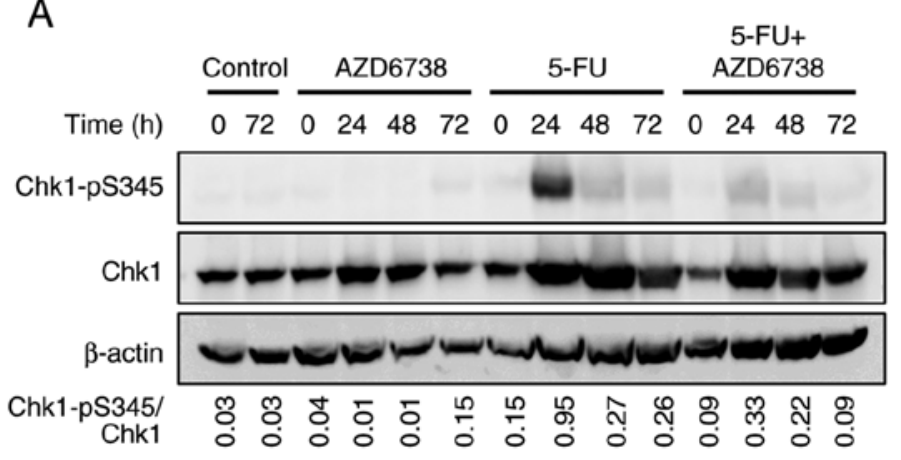

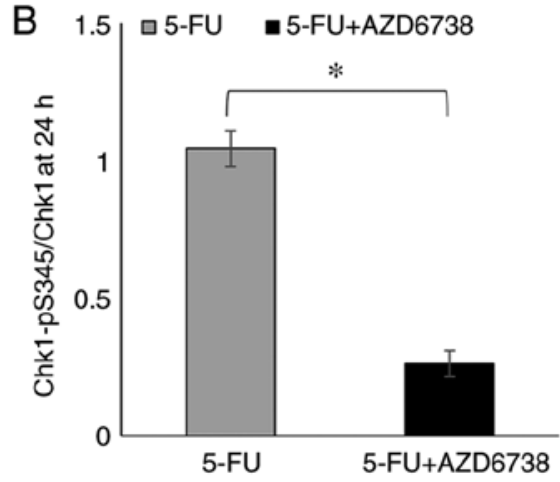

Figure 2. AZD6738 reduces the levels of 5-FU-induced phosphorylation of Chk1. HT29 cells were treated with 5-FU $(5 \mu \mathrm{M})$ in the presence or absence of AZD6738 $(0.5 \mu \mathrm{M})$. (A) Cells were harvested at the times indicated, and total cell extracts were subjected to western blotting using various antibodies (Chk1-pS345, Chk1 and $\beta$-actin). (B) Chk1-pS345/Chk1 at $24 \mathrm{~h}$ were shown. Data are presented as the mean \pm SD ( $\mathrm{n}=3$ ). Statistical significance was calculated using Student's t-test. "P<0.05 vs. 5-FU. 5-FU, 5-fluorouracil; Chk1, checkpoint kinase 1; Chk1-pS345, phospho-Chk1 Ser345.

A

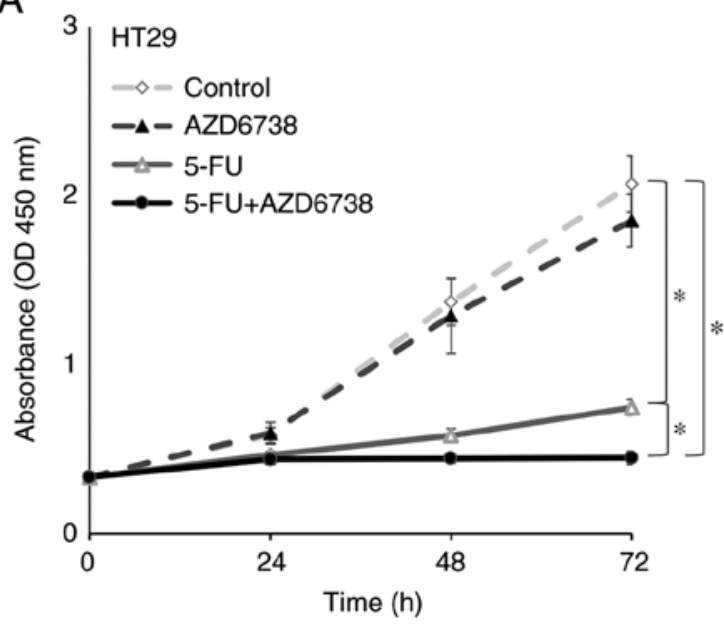

B

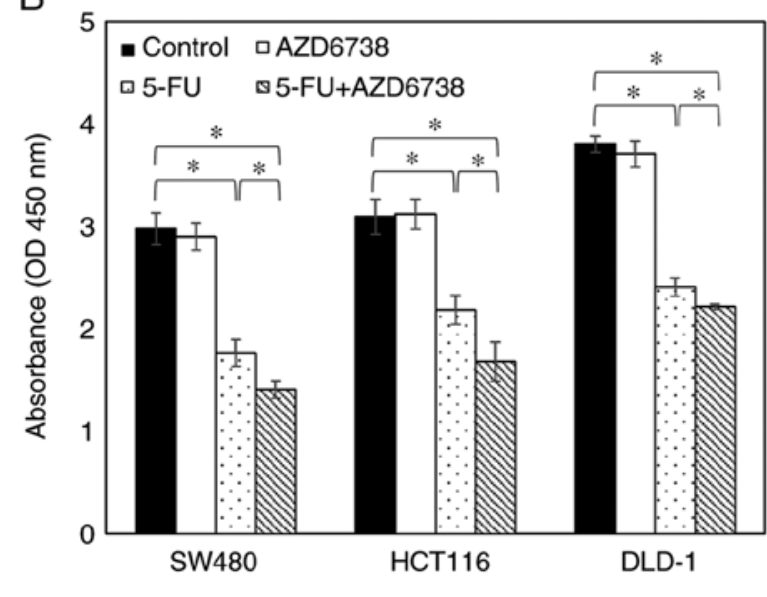

Figure 3. Combination treatment of AZD6738 with 5-FU effectively suppresses cell viability. (A) HT29 cells were treated with AZD6738 (0.5 $\mu$ M) in combination with 5-FU $(5 \mu \mathrm{M})$ for the indicated times, followed by a WST-1 assay. (B) Several colorectal cancer cell lines (SW480, HCT116 and DLD-1) were treated with AZD6738 $(0.5 \mu \mathrm{M})$ in combination with 5-FU for $72 \mathrm{~h}$, followed by a WST-1 assay. The cells were treated with the half-maximal inhibitory concentrations of 5-FU: $25 \mu \mathrm{M}$ for SW480 and DLD-1 cells and $5 \mu \mathrm{M}$ for HCT116 cells. Data are presented as the mean \pm SD (n=6). Statistical significance was calculated using Tukey's test after one-way ANOVA ( $\left.{ }^{*} \mathrm{P}<0.05\right)$. 5-FU, 5-fluorouracil; OD, optical density; WST-1, water-soluble tetrazolium 1.

S phase was increased in the 5-FU+AZD6738 combination group compared with the 5-FU alone group. The AZD6738 alone group was comparable to the control group in the cell cycle.

To confirm the percentage of cells that have entered the $\mathrm{M}$ phase, nocodazole was used as shown in Fig. 1B. Phospho-histone H3 at S10 was used as a marker for mitotic cells. The percentage of cells positive for phospho-histone $\mathrm{H} 3$ at $\mathrm{S} 10$ was measured by flow cytometry. The mitotic cells were increased significantly in the presence of AZD6738 $(\mathrm{P}<0.05$; Fig. 1C and D). These results indicated that AZD6738 inhibited 5-FU-induced activation of the $\mathrm{G}_{2}$ checkpoint.

AZD6738 reduces the level of phosphorylated Chk1. AZD6738 inhibits ATR by inhibiting the phosphorylation of Chk1 $(19,20)$. If 5-FU induces DNA damage, Chk1 phosphorylation at the $\mathrm{G}_{2}$ checkpoint occurs as a consequence (34). The present study examined whether this effect is inhibited by AZD6738 in HT29 cells. After 5-FU monotherapy, Chk1 phosphorylation at S345 was strongly detected at $24 \mathrm{~h}$, whereas the 5-FU/AZD6738 combination suppressed the phosphorylation of Chk1 (Fig. 2).

AZD6738/5-FU combination treatment suppresses the survival of colorectal cancer cells. Next, to examine whether inhibition of the $\mathrm{G}_{2}$ checkpoint suppresses cell survival, a WST-1 assay was performed using HT29 cells and the synergistic effect of AZD6738 and 5-FU on cell survival at 24, 48 and $72 \mathrm{~h}$ was investigated. At 24 and $48 \mathrm{~h}$, there was no significant difference between cells treated with 5-FU alone and those treated with both AZD6738 and 5-FU. However, at $72 \mathrm{~h}$, cell survival was significantly decreased in the AZD6738/5-FU combination group compared with the 5-FU alone group $(\mathrm{P}<0.05$; Fig. 3A).

The present study subsequently investigated the synergistic effect of AZD6738 and 5-FU on the survival of other p53-deficient colorectal cancer cells. SW480, HCT116 and DLD-1 cells were treated with both 5-FU and AZD6738 for $72 \mathrm{~h}$, which effectively inhibited cell survival compared with 5-FU alone in all three cell lines $(\mathrm{P}<0.05$; Fig. $3 \mathrm{~B})$. 
A
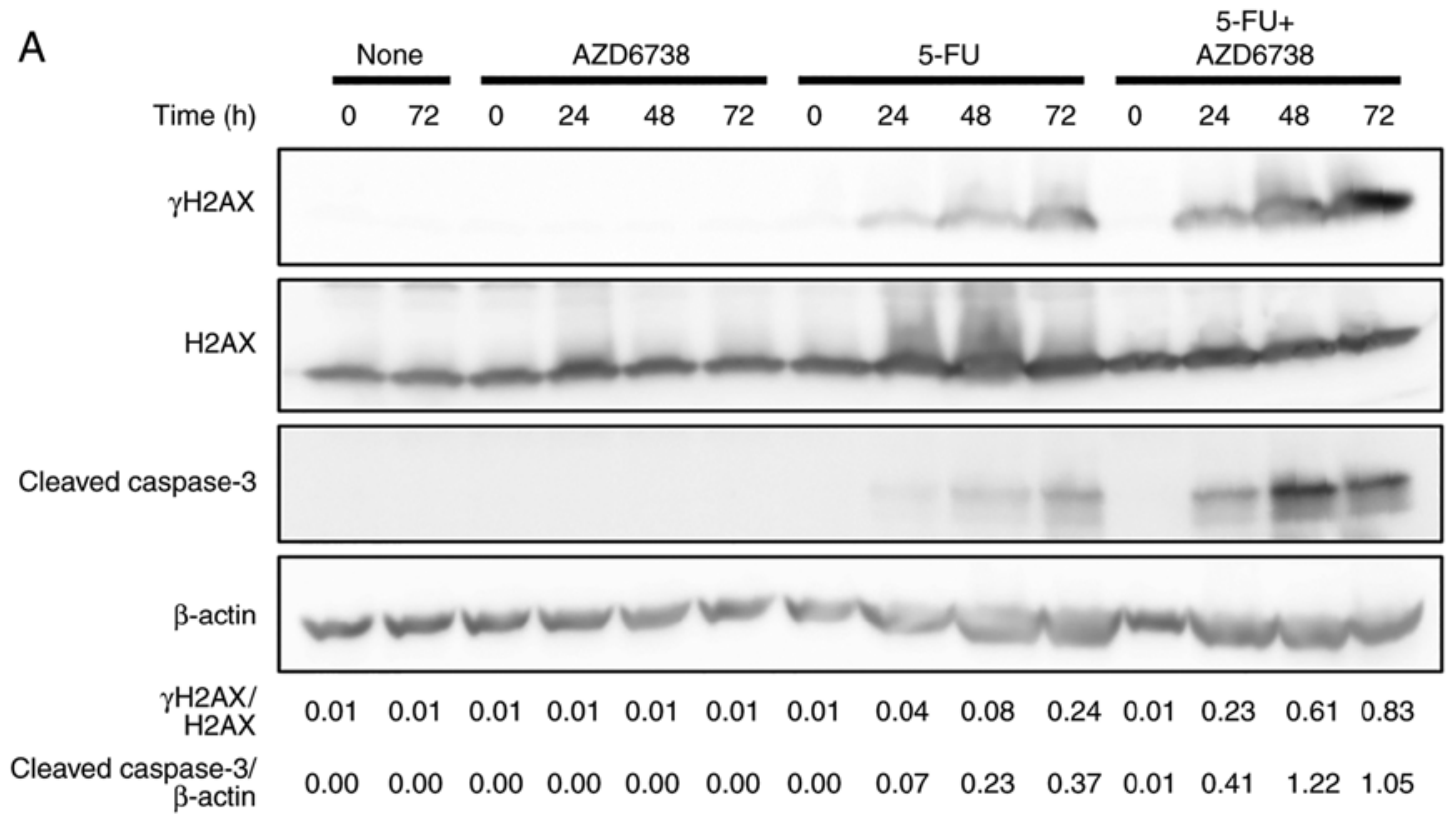

B
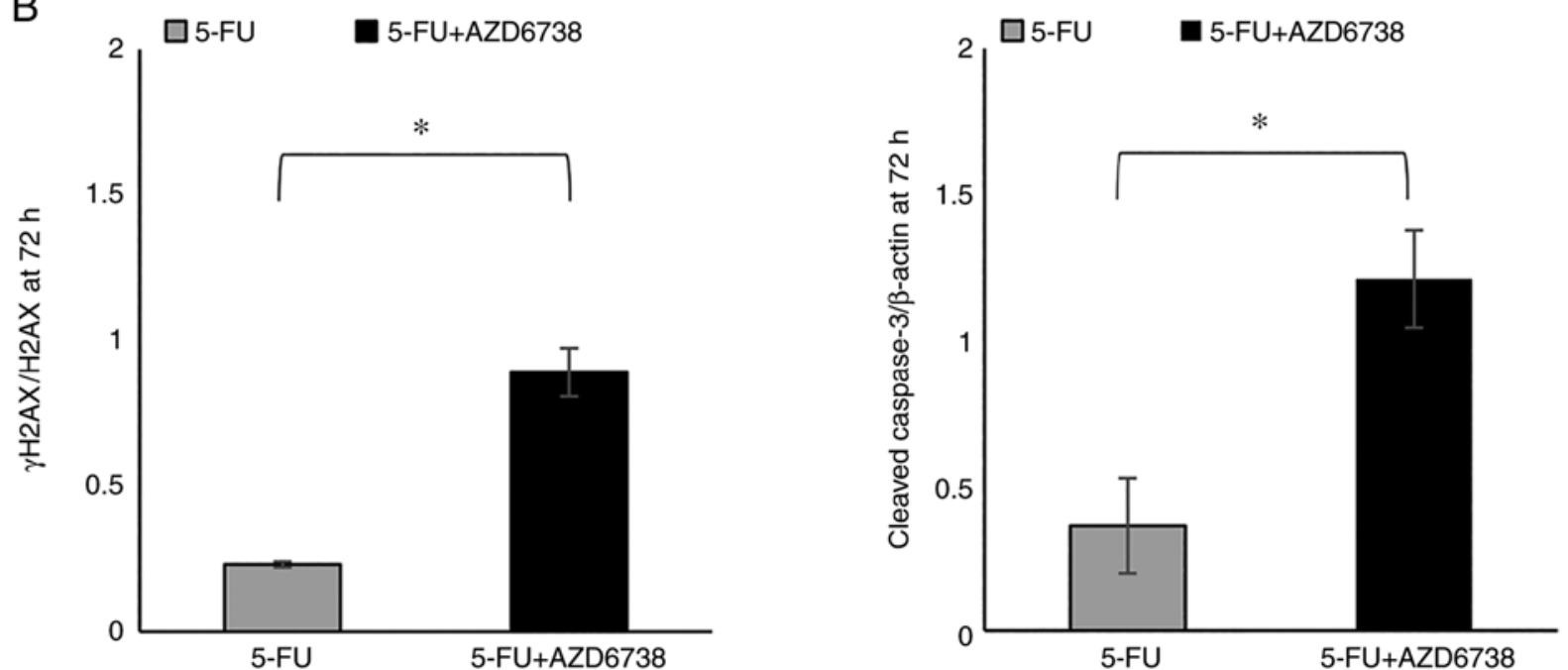

Figure 4. AZD6738 enhances 5-FU-induced apoptosis in HT29 cells. (A) HT29 cells were treated with AZD6738 (0.5 $\mu$ M) in combination with 5-FU (5 $\mu$ M). Cells were harvested at the indicated times. Whole cell extracts were subjected to western blotting using various antibodies $(\gamma \mathrm{H} 2 \mathrm{AX}, \mathrm{H} 2 \mathrm{AX}$, cleaved-caspase-3 and $\beta$-actin). (B) $\gamma \mathrm{H} 2 \mathrm{AX} / \mathrm{H} 2 \mathrm{AX}$ and cleaved-caspase-3/ $\beta$-actin at $72 \mathrm{~h}$. Data are presented as the mean $\pm \mathrm{SD}(\mathrm{n}=3)$. Statistical significance was calculated using Student's t-test. " $\mathrm{P}<0.05$ vs. 5-FU. 5-FU, 5-fluorouracil; H2AX, H2A.X variant histone; $\gamma \mathrm{H} 2 \mathrm{AX}$, phosphorylated form of H2AX.

AZD6738 enhances 5-FU-mediated apoptosis and DNA damage. The present study examined whether the combination of AZD6738 and 5-FU increases cell death. The levels of cleaved caspase-3, a marker of apoptosis, and those of $\gamma \mathrm{H} 2 \mathrm{AX}$, a marker of DNA damage, were increased after the combination treatment compared with 5-FU monotherapy at $72 \mathrm{~h}$ (Fig. 4). These results indicated that the treatment of 5-FU combined with AZD6738 caused accumulation of DNA damage and increased apoptosis.

AZD6738 enhances 5-FU-induced inhibition of tumor growth and DNA damage in mouse xenograft models. To determine whether AZD6738 enhances the therapeutic effect of 5-FU in vivo, a HT29 subcutaneous xenograft model was developed in nude mice. Once the tumors had developed, each treatment was administered for 3 weeks. As shown in Fig. 5, the 5-FU/AZD6738 combination treatment resulted in significantly greater inhibition of tumor growth compared with 5 -FU (25 mg/kg 5 days/week) monotherapy at 3 weeks $(\mathrm{P}<0.05$; Fig. 5A). There was no significant difference in tumor growth between the AZD6738 alone group and the control group (Fig. S2).

In addition, immunohistochemical staining of $\gamma \mathrm{H} 2 \mathrm{AX}$ revealed a significant increase in the percentage of $\gamma \mathrm{H} 2 \mathrm{AX}$-positive cells in the AZD6738 combination $(9.82 \%)$ group compared with the 5-FU monotherapy group $(3.55 \%)$ $(\mathrm{P}<0.05$; Fig. 5C-E). Thus, in vivo, the combination of $5-\mathrm{FU}$ and AZD6738 increased DNA damage in cancer cells and enhanced tumor growth inhibition compared with 5-FU alone.

\section{Discussion}

The increasing resistance to chemotherapy or radiotherapy, or both, in malignant tumors causes major difficulties in their 

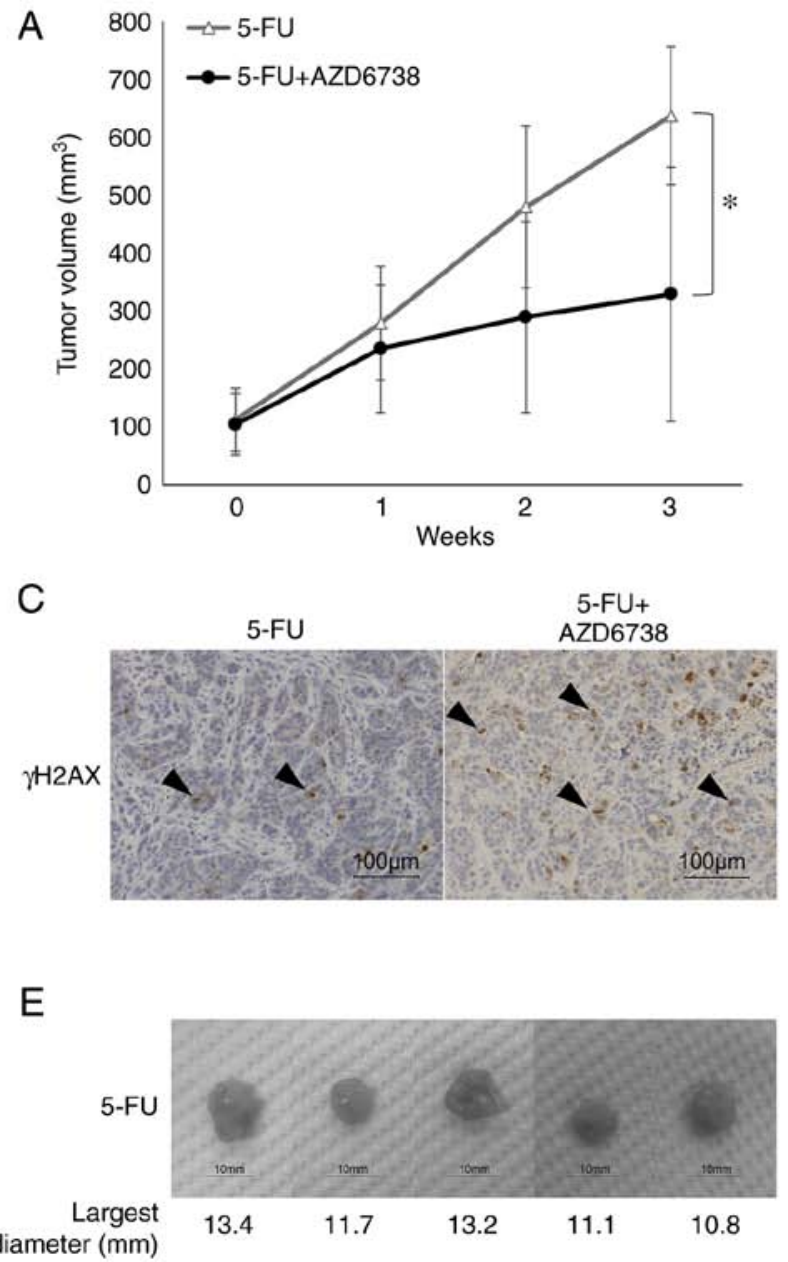

B

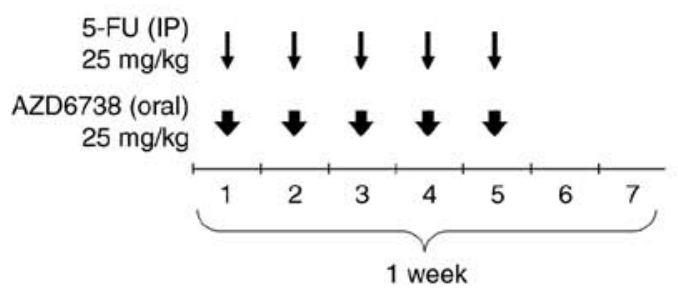

D
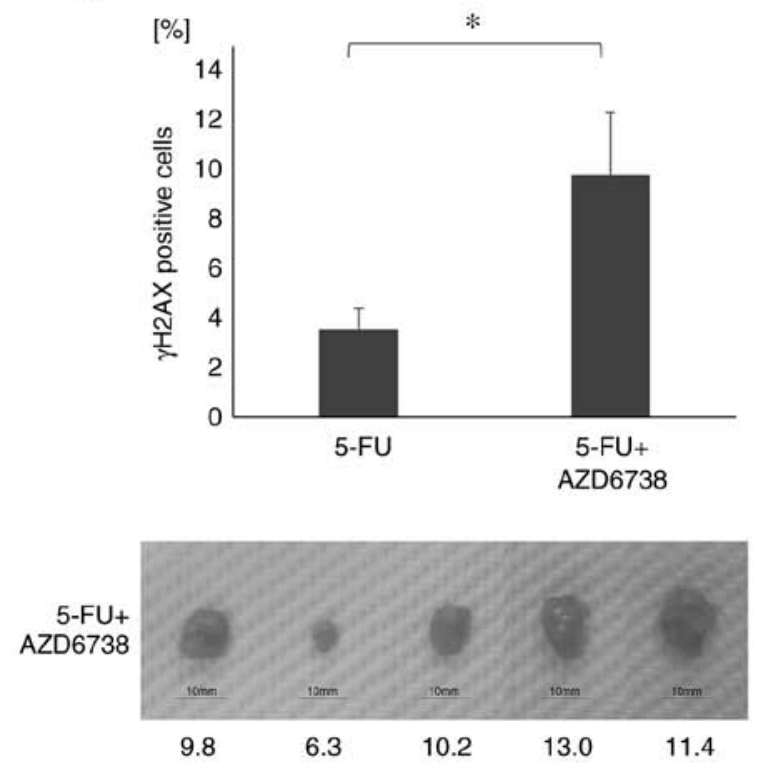

Figure 5. Combination treatment of AZD6738 with 5-FU effectively suppresses tumor growth in a HT29 xenograft mouse model. (A) Tumor volume in xenograft models was measured after various treatments (5-FU and AZD6738/5-FU combination). Data are presented as the mean \pm SD (n=5). Statistical significance was calculated using Student's t-test (unpaired) at the last time point ( $\left.{ }^{*} \mathrm{P}<0.05\right)$. (B) Schematic of the dose schedule of the AZD6738/5-FU combination treatment. (C) Representative images (magnification, x200; Scale bar, $100 \mu \mathrm{m} ; \gamma \mathrm{H} 2 \mathrm{AX}$ ). The arrowheads indicate $\gamma \mathrm{H} 2 \mathrm{AX}$-positive cells. (D) Quantification of $\gamma \mathrm{H} 2 \mathrm{AX}$-positive cells. Data are presented as the mean $\pm \mathrm{SD}(\mathrm{n}=5)$. Statistical significance was calculated using Student's t-test ( $\mathrm{P}<0.05)$. (E) Images of excised tumors. 5-FU, 5-fluorouracil; $\gamma \mathrm{H} 2 \mathrm{AX}$, phosphorylated form of H2A.X variant histone; IP, intraperitoneal.

treatment and management. It has been reported that cancer cells may acquire therapeutic resistance by activating specific DNA repair pathways (35), and focusing on this process is important for predicting the treatment response and developing novel therapeutic strategies to prevent the emergence of treatment resistance. Therefore, the combination of cytotoxic agents with chemosensitizing agents, such as inhibitors of cell cycle checkpoints or of DNA repair pathways, is likely to result in synthetic lethality in specific types of cancer cells.

A number of $\mathrm{G}_{2}$ checkpoint inhibitors have been developed, and several of these have been proposed as promising candidates for treating p53-deficient cancer cells because survival of these cells after DNA damage is dependent on the ATR/Chk1-mediated $\mathrm{G}_{2}$ checkpoint $(36,37)$. In this context, ATR has been considered a promising therapeutic target because it is an essential kinase for $G_{2}$ arrest in response to various genotoxic stresses (38). However, a number of checkpoint kinases also serve an important role in normal cell survival and genome maintenance, and their inhibition may have unexpected adverse effects on normal cell function (38). To be used as a clinical therapeutic agent, specificity to the target kinase is more important (39). The first ATR inhibitor, Schisandrin B, has been reported to abrogate the UV-induced $G_{2}$ checkpoint, but its efficacy against ATR is insufficient for clinical use (40). Since then, ATR-selective inhibitors, such as VE-821 $(41,42)$ and AZ20 (43), have been developed. AZD6738, used in the present study, is an ATR-selective agent with superior solubility, bioavailability and pharmacokinetic properties compared with other agents $(18,44)$. Also known as ceralasetrib, AZD6738 is currently undergoing phase I and II trials (24); however, to the best of our knowledge, no studies have evaluated its effect in combination with 5-FU. One of our previous studies elucidated the mechanism of action of CBP-93872 (6), a $G_{2}$ checkpoint inhibitor, and another one of our previous studies reported its efficacy in combination with radiotherapy and multiple anticancer agents (34). Based on this, the present study focused on AZD6738.

5 -FU serves a central role in the treatment of colorectal cancer in the first and second chemotherapy lines. It has three mechanisms of action: DNA damage by its uptake into DNA (1), RNA damage by its uptake into RNA (45) and the inhibition of DNA de novo synthesis by inhibition of thymidylate synthase (TS) (46). In the case of DNA damage, 5-FU 
taken into cells is converted into 5-fluoro-2'-deoxyuridine 5 '-monophosphate (FdUMP). After that it is converted into 5-fluoro-2'-deoxyuridine 5'-triphosphate and taken into DNA $(47,48)$. Such replication stress causes DNA damage and activates ATR, which phosphorylates multiple downstream substrates responsible for the DDR (6). Cells can stabilize their DNA and survive replication stress by preventing firing of replication origins, stabilizing arrested replication forks, and promoting DNA repair and cell cycle checkpoints (6). The simultaneous use of AZD6738 and 5-FU is likely to inhibit these processes. Therefore, AZD6738-induced cell death may be mediated by destabilization of one or more of the aforementioned pathways.

Another effect of 5-FU on the cell cycle is arrest in the $S$ phase (49). This cell cycle arrest is due to inhibition of DNA synthesis. By forming a ternary complex with TS and 5,10-methylenetetrahydrofolate, FdUMP inhibits TS, which in turn causes a reduction in deoxythymidine monophosphate, which is required for deoxythymidine triphosphate synthesis, ultimately leading to thymidine depletion and $S$ phase arrest (49). In the present study, although 5-FU induced S-phase arrest when combined with AZD6738, this was followed by inhibition of the $G_{2}$ checkpoint, which enhanced the effect of 5-FU both in vitro and in vivo.

AZD6738 specifically suppresses the $G_{2}$ checkpoint by inhibiting DNA damage-dependent activation of ATR (39). Importantly, AZD6738 has little effect on normal cells because normal cells have a functioning ATM/p53/p21 signaling pathway (6). The present results suggest that AZD6738, when used in combination with 5-FU, has the potential to enhance the therapeutic effect of chemotherapy on colorectal cancer by efficiently acting from the first line and preventing resistance.

\section{Acknowledgements}

The authors would like to thank Ms Seiko Inumaru and Ms Ryoko Hara for handling tumor samples in the present study (Department of Gastroenterological Surgery, Nagoya City University Graduate School of Medical Sciences, Nagoya, Japan).

\section{Funding}

The present study was supported by Grants-in-Aid for Scientific Research (Japan Society for the Promotion of Science; grant no. 19K18158).

\section{Availability of data and materials}

All data generated or analyzed during this study are included in this published article.

\section{Authors' contributions}

TS and TH contributed to the conception and design of the study, analyzed and interpreted the data, and wrote and reviewed the manuscript. AMa, KW, TY, NN, YMae, KS, RO, AMi, MK, YMae, HT and ST designed the study. AMa, SH, $\mathrm{KW}, \mathrm{HU}, \mathrm{NN}$, YMat and HT analyszd and interpreted data. TS, SH, HU, AMa, AMi and MK acquired the data. TS, TH,
AMi, KW and MK confirm the authenticity of all the raw data. TS, TH, SH, KW and HT wrote the manuscript. TH, YMat, AMi and ST supervised the study. All authors read and approved the final manuscript.

\section{Ethics approval and consent to participate}

In vivo mouse experiments were performed according to the Guidelines for Animal Experiments of the Nagoya City University Graduate School of Medical Sciences and approved by the Animal Care and Use Committee of the Nagoya City University Graduate School of Medical Sciences (reference number, 20-011; Nagoya, Japan).

\section{Patient consent for publication}

Not applicable.

\section{Competing interests}

The authors declare that they have no competing interests.

\section{References}

1. Saito K, Nagashima H, Noguchi K, Yoshisue K, Yokogawa T, Matsushima E, Tahara T and Takagi S: First-in-human, phase I dose-escalation study of single and multiple doses of a first-in-class enhancer of fluoropyrimidines, a dUTPase inhibitor (TAS-114) in healthy male volunteers. Cancer Chemother Pharmacol 73: 577-583, 2014.

2. Ghosh S: Cisplatin: The first metal based anticancer drug. Bioorg Chem 88: 102925, 2019.

3. Ward JF: DNA damage produced by ionizing radiation in mammalian cells: Identities, mechanisms of formation, and reparability. Prog Nucleic Acid Res Mol Biol 35: 95-125, 1988.

4. Blondy S, David V, Verdier M, Mathonnet M, Perraud A and Christou N: 5-Fluorouracil resistance mechanisms in colorectal cancer: From classical pathways to promising processes. Cancer Sci 111: 3142-3154, 2020.

5. Harper JW and Elledge SJ: The DNA damage response: Ten years after. Mol Cell 28: 739-745, 2007.

6. Hirokawa T, Shiotani B, Shimada M, Murata K, Johmura Y, Haruta M, Tahara H, Takeyama H and Nakanishi M: CBP-93872 inhibits NBS1-mediated ATR activation, abrogating maintenance of the DNA double-strand break-specific G2 checkpoint. Cancer Res 74: 3880-3889, 2014.

7. Shimada M and Nakanishi M: DNA damage checkpoints and cancer. J Mol Histol 37: 253-260, 2006.

8. Niida H, Katsuno Y, Banerjee B, Hande MP and Nakanishi M: Specific role of Chk1 phosphorylations in cell survival and checkpoint activation. Mol Cell Biol 27: 2572-2581, 2007.

9. Shimada M, Niida H, Zineldeen DH, Tagami H, Tanaka M, Saito $\mathrm{H}$ and Nakanishi M: Chk1 is a histone H3 threonine 11 kinase that regulates DNA damage-induced transcriptional repression. Cell 132: 221-232, 2008.

10. Shimada $M$ and Nakanishi $M$ : Checkpoints meet the transcription at a novel histone milestone (H3-T11). Cell Cycle 7: $1555-1559,2008$

11. Liu Q, Guntuku S, Cui XS, Matsuoka S, Cortez D, Tamai K, Luo G, Carattini-Rivera S, DeMayo F, Bradley A, et al: Chk1 is an essential kinase that is regulated by Atr and required for the G(2)/M DNA damage checkpoint. Genes Dev 14: 1448-1459, 2000.

12. Iacopetta B: TP53 mutation in colorectal cancer. Hum Mutat 21: 271-276, 2003.

13. Kandoth C, McLellan MD, Vandin F, Ye K, Niu B, Lu C, Xie M, Zhang Q, McMichael JF, Wyczalkowski MA, et al: Mutational landscape and significance across 12 major cancer types. Nature 502: 333-339, 2013.

14. Song Y, Li L, Ou Y, Gao Z, Li E, Li X, Zhang W, Wang J, Xu L, Zhou Y, et al: Identification of genomic alterations in oesophageal squamous cell cancer. Nature 509: 91-95, 2014. 
15. Fan S, Smith ML, Rivet DJ II, Duba D, Zhan Q, Kohn KW, Fornace AJ Jr and O'Connor PM: Disruption of p53 function sensitizes breast cancer MCF-7 cells to cisplatin and pentoxifylline. Cancer Res 55: 1649-1654, 1995.

16. Goto H, Izawa I, Li P and Inagaki M: Novel regulation of checkpoint kinase 1: Is checkpoint kinase 1 a good candidate for anti-cancer therapy? Cancer Sci 103: 1195-1200, 2012.

17. Ma CX, Janetka JW and Piwnica-Worms H: Death by releasing the breaks: CHK1 inhibitors as cancer therapeutics. Trends Mol Med 17: 88-96, 2011.

18. Sundar R, Brown J, Ingles Russo A and Yap TA: Targeting ATR in cancer medicine. Curr Probl Cancer 41: 302-315, 2017.

19. Vendetti FP, Lau A, Schamus S, Conrads TP, O'Connor MJ and Bakkenist CJ: The orally active and bioavailable ATR kinase inhibitor AZD6738 potentiates the anti-tumor effects of cisplatin to resolve ATM-deficient non-small cell lung cancer in vivo. Oncotarget 6: 44289-44305, 2015.

20. Foote KM, Nissink JWM, McGuire T, Turner P, Guichard S, Yates JW, Lau A, Blades K, Heathcote D, Odedra R, et al: Discovery and characterization of AZD6738, a potent inhibitor of ataxia telangiectasia mutated and Rad3 related (ATR) kinase with application as an anticancer agent. J Med Chem 61: 9889-9907, 2018.

21. Wallez Y, Dunlop CR, Johnson TI, Koh SB, Fornari C, Yates JWT, Bernaldo de Quirós Fernández S, Lau A, Richards FM and Jodrell DI: The ATR inhibitor AZD6738 synergizes with gemcitabine in vitro and in vivo to induce pancreatic ductal adenocarcinoma regression. Mol Cancer Ther 17: 1670-1682, 2018.

22. Dok R, Glorieux M, Bamps M and Nuyts S: Effect of ATR Inhibition in RT response of HPV-negative and HPV-positive head and neck cancers. Int J Mol Sci 22: 1504, 2021.

23. Dillon MT, Barker HE, Pedersen M, Hafsi H, Bhide SA, Newbold KL, Nutting CM, McLaughlin M and Harrington KJ: Radiosensitization by the ATR inhibitor AZD6738 through generation of acentric micronuclei. Mol Cancer Ther 16: 25-34, 2017.

24. Gorecki L, Andrs M, Rezacova M and Korabecny J: Discovery of ATR kinase inhibitor berzosertib (VX-970, M6620): Clinical candidate for cancer therapy. Pharmacol Ther 210: 107518, 2020.

25. Kim R, Kwon M, An M, Kim ST, Smith SA, Loembé AB Mortimer PGS, Armenia J, Lukashchuk N, Shah N, et al: Phase II study of ceralasertib (AZD6738) in combination with durvalumab in patients with advanced/metastatic melanoma who have failed prior anti-PD-1 therapy. Ann Oncol 33: 193-203, 2022.

26. Shah PD, Wethington SL, Pagan C, Latif N, Tanyi J, Martin LP, Morgan M, Burger RA, Haggerty A, Zarrin H, et al: Combination ATR and PARP Inhibitor (CAPRI): A phase 2 study of ceralasertib plus olaparib in patients with recurrent, platinum-resistan epithelial ovarian cancer. Gynecol Oncol 163: 246-253, 2021

27. Dillon MT, Boylan Z, Smith D, Guevara J, Mohammed K, Peckitt C, Saunders M, Banerji U, Clack G, Smith SA, et al PATRIOT: A phase I study to assess the tolerability, safety and biological effects of a specific ataxia telangiectasia and Rad3-related (ATR) inhibitor (AZD6738) as a single agent and in combination with palliative radiation therapy in patients with solid tumours. Clin Transl Radiat Oncol 12: 16-20, 2018.

28. Yap TA, Krebs MG, Postel-Vinay S, Bang YJ, El-Khoueiry A, Abida W, Harrington K, Sundar R, Carter L, Castanon-Alvarez E, et al: Phase I modular study of AZD6738, novel oral, potent and selective ataxia telangiectasia Rad3-related (ATR) inhibitor in combination (combo) with carboplatin, olaparib or durvalumab in patients (pts) with advanced cancers. Eur J Cancer 69 (Suppl 1): S2, 2016.

29. Young LA, O'Connor LO, de Renty C, Veldman-Jones MH, Dorval T, Wilson Z, Jones DR, Lawson D, Odedra R, Maya-Mendoza A, et al: Differential activity of ATR and WEE1 inhibitors in a highly sensitive subpopulation of DLBCL linked to replication stress. Cancer Res 79: 3762-3775, 2019.

30. Nam AR, Jin MH, Bang JH, Oh KS, Seo HR, Oh DY and Bang YJ: Inhibition of ATR increases the sensitivity to WEE1 inhibitor in biliary tract cancer. Cancer Res Treat 52: 945-956, 2020.

31. Min A, Im SA, Jang H, Kim S, Lee M, Kim DK, Yang Y, Kim HJ, Lee KH, Kim JW, et al: AZD6738, A novel oral inhibitor of ATR, induces synthetic lethality with ATM deficiency in gastric cancer cells. Mol Cancer Ther 16: 566-577, 2017.

32. Shimabukuro M, Hayashi K, Kishida R, Tsuchiya A and Ishikawa K: No-observed-effect level of silver phosphate in carbonate apatite artificial bone on initial bone regeneration. ACS Infect Dis 8: 159-169, 2022.
33. Rodrigues NR, Rowan A, Smith ME, Kerr IB, Bodmer WF, Gannon JV and Lane DP: p53 mutations in colorectal cancer. Proc Natl Acad Sci USA 87: 7555-7559, 1990.

34. Iwata T, Uchino T, Koyama A, Johmura Y, Koyama K, Saito T, Ishiguro S, Arikawa T, Komatsu S, Miyachi M, et al: The G2 checkpoint inhibitor CBP-93872 increases the sensitivity of colorectal and pancreatic cancer cells to chemotherapy. PLoS One 12: e0178221, 2017

35. Stover EH, Konstantinopoulos PA, Matulonis UA and Swisher EM: Biomarkers of response and resistance to DNA repair targeted therapies. Clin Cancer Res 22: 5651-5660, 2016.

36. Landau HJ, McNeely SC, Nair JS, Comenzo RL, Asai T, Friedman H, Jhanwar SC, Nimer SD and Schwartz GK: The checkpoint kinase inhibitor AZD7762 potentiates chemotherapy-induced apoptosis of p53-mutated multiple myeloma cells. Mol Cancer Ther 11: 1781-1788, 2012.

37. Meng X, Laidler LL, Kosmacek EA, Yang S, Xiong Z, Zhu D, Wang X, Dai D, Zhang Y, Wang X, et al: Induction of mitotic cell death by overriding $\mathrm{G} 2 / \mathrm{M}$ checkpoint in endometrial cancer cells with non-functional p53. Gynecol Oncol 128: 461-469, 2013.

38. Liu S, Shiotani B, Lahiri M, Maréchal A, Tse A, Leung CC, Glover JN, Yang XH and Zou L: ATR autophosphorylation as a molecular switch for checkpoint activation. Mol Cell 43: 192-202, 2011.

39. Foote KM, Lau A and Nissink JW: Drugging ATR: Progress in the development of specific inhibitors for the treatment of cancer. Future Med Chem 7: 873-891, 2015.

40. Nishida H, Tatewaki N, Nakajima Y, Magara T, Ko KM, Hamamori Y and Konishi T: Inhibition of ATR protein kinase activity by schisandrin B in DNA damage response. Nucleic Acids Res 37: 5678-5689, 2009.

41. Charrier JD, Durrant SJ, Golec JM, Kay DP, Knegtel RM, MacCormick S, Mortimore M, O'Donnell ME, Pinder JL, Reaper PM, et al: Discovery of potent and selective inhibitors of ataxia telangiectasia mutated and Rad3 related (ATR) protein kinase as potential anticancer agents. J Med Chem 54: 2320-2330, 2011.

42. Śalovská B, Fabrik I, Duurišová K,Link M, Vávrová J, Řezáčová M and Tichý A: Radiosensitization of human leukemic HL-60 cells by ATR kinase inhibitor (VE-821): Phosphoproteomic analysis. Int J Mol Sci 15: 12007-12026, 2014.

43. Foote KM, Blades K, Cronin A, Fillery S, Guichard SS, Hassall L, Hickson I, Jacq X, Jewsbury PJ, McGuire TM, et al: Discovery of 4-\{4-[(3R)-3-Methylmorpholin-4-yl]-6-[1-(methylsulfonyl) cyclopropyl]pyrimidin-2-yl\}-1H-indole (AZ20): A potent and selective inhibitor of ATR protein kinase with monotherapy in vivo antitumor activity. J Med Chem 56: 2125-2138, 2013.

44. Jones CD, Blades K, Foote KM, Guichard SM, Jewsbury PJ, McGuire T, Nissink JW, Odedra R, Tam K, Thommes P, et al: Abstract 2348: Discovery of AZD6738, a potent and selective inhibitor with the potential to test the clinical efficacy of ATR kinase inhibition in cancer patients. Cancer Res 73 (Suppl 8): S2348, 2013.

45. Chalabi-Dchar M, Fenouil T, Machon C, Vincent A, Catez F, Marcel V, Mertani HC, Saurin JC, Bouvet P, Guitton J, et al: A novel view on an old drug, 5-fluorouracil: An unexpected RNA modifier with intriguing impact on cancer cell fate. NAR Cancer 3: zcab032, 2021

46. Very N, Hardivillé S, Decourcelle A, Thévenet J, Djouina M, Page A, Vergoten G, Schulz C, Kerr-Conte J, Lefebvre T, et al Thymidylate synthase O-GlcNAcylation: A molecular mechanism of 5-FU sensitization in colorectal cancer. Oncogene 41: 745-756, 2022

47. Longley DB, Harkin DP and Johnston PG: 5-fluorouracil: Mechanisms of action and clinical strategies. Nat Rev Cancer 3: 330-338, 2003

48. Mori R, Yoshida K, Futamura M, Suetsugu T, Shizu K, Tanahashi T, Tanaka Y, Matsuhashi N and Yamaguchi K: The inhibition of thymidine phosphorylase can reverse acquired 5FU-resistance in gastric cancer cells. Gastric Cancer 22: 497-505, 2019

49. Hagenkort A, Paulin CBJ, Desroses M, Sarno A, Wiita E, Mortusewicz O, Koolmeister T, Loseva O, Jemth AS, Almlöf I, et al: dUTPase inhibition augments replication defects of 5-fluorouracil. Oncotarget 8: 23713-23726, 2017.

This work is licensed under a Creative Commons Attribution-NonCommercial-NoDerivatives 4.0 International (CC BY-NC-ND 4.0) License. 